\title{
Nucleophilic and free-radical additions of phosphines and phosphine chalcogenides to alkenes and alkynes
}

\author{
Svetlana N. Arbuzova, Nina K. Gusarova, and Boris A. Trofimov* \\ A.E. Favorsky Irkutsk Institute of Chemistry, Siberian Branch of Russian Academy of Sciences, \\ 1 Favorsky St., Irkutsk, 664033 Russia \\ E-mail: boris trofimov@irioch.irk.ru
}

Dedicated to Professor E. Lukevics on the occasion of his $70^{\text {th }}$ anniversary

\begin{abstract}
Nucleophilic and free-radical additions of phosphines and phosphine chalcogenides to alkenes and alkynes are discussed. The bibliography includes 169 references.
\end{abstract}

Keywords: Phosphines, phosphine chalcogenides, alkenes, alkynes, addition

\section{Table of contents}

1. Introduction

2. Addition of phosphines and phosphine chalcogenides to alkenes

2.1 Nucleophilic addition of phosphines and phosphine chalcogenides to alkenes

2.1.1 Phosphine

2.1.2 Primary and secondary phosphines and phosphine chalcogenides

2.2 Radical addition of phosphines and phosphine chalcogenides to alkenes

2.2.1 Phosphine

2.2.2 Primary and secondary phosphines

2.2.3 Secondary phosphine chalcogenides

3. Nucleophilic addition of phosphines and phosphine chalcogenides to alkynes

3.1 Phosphine

3.2 Primary phosphines

3.3 Secondary phosphines

3.4 Secondary phosphine chalcogenides

4. Conclusion

5. References 


\section{Introduction}

Addition of phosphines and phosphine chalcogenides to double and triple carbon-carbon bonds represents a convenient and atom-economic approach to $\mathrm{C}-\mathrm{P}$ bond formation and synthesis of functional phosphines and phosphine chalcogenides. ${ }^{1-4}$ These compounds are important objects in the chemistry of organophosphorus compounds and widely applied as ligands for advanced catalysts (including those for enantioselective processes ${ }^{5-11}$ ), flame retardants, ${ }^{12,13}$ extractants of rare earth and transuranic elements, ${ }^{14}$ building blocks and starting materials for the preparation of biologically active compounds for medicine and agriculture. ${ }^{15-18}$ Over the recent years, a lot of research has been devoted to addition reactions of $\mathrm{P}-\mathrm{H}$ reagents to multiple carbon-carbon bonds, catalyzed by metal complexes, and, as a result, numerous synthetic methods have been developed (for example, see the reviews ${ }^{19-23}$ ). Meanwhile, hydrophosphination of alkenes and alkynes under base-catalyzed or free-radical conditions (i.e., under "green chemistry" conditions) often appears to be competitive, let alone ecologically safer, and sometimes experimentally even more advantageous.

In this review, we survey and analyze results of the investigations concerning the heavy metal-free additions of phosphines and phosphine chalcogenides, containing a P-H function, to multiple carbon-carbon bonds. The attention is focused on the work of the last 10 years, relating to synthesis of functional phosphines and phosphine chalcogenides through reactions of phosphine, primary and secondary phosphines, phosphine oxides and sulfides with substituted alkenes and alkynes. For this period a number of new or earlier inaccessible P-H species became readily available owing to the methodology for the activation of elemental phosphorus in heterogeneous strongly basic media ${ }^{24,25}$ developed in late $80-\mathrm{s}^{26-31}$ (now often referred to as the Trofimov-Gusarova reaction ${ }^{32,33}$ ). This new approach to the $\mathrm{C}-\mathrm{P}$ bond formation allows one to carry out direct phosphorylations of organohalides, dihaloalkanes, electrophilic alkenes, acetylenes and oxiranes with elemental phosphorus to afford diverse primary, secondary and tertiary phosphines and phosphine chalcogenides, including functionalized and unsaturated

ones. $^{34-38}$ Some of the P-H compounds derived from these reactions turned out to be rewarding addends for nucleophilic and free-radical additions to multiple bonds, thus further unfolding the field.

\section{Addition of phosphines and phosphine chalcogenides to alkenes}

Electrophilic addition of such P-H addends as phosphines and their chalcogenides to unsaturated compounds is not as extensively studied as their nucleophilic and free-radical additions. Among scarce examples of these reactions ${ }^{4,39-41}$ phosphine was reported to react with alkenes in the presence of acids under pressure $\left(60-90^{\circ} \mathrm{C}, 30-47 \mathrm{~atm}\right)$ to give mostly primary Markovnikov phosphines. ${ }^{39}$ Secondary phosphines add to alkyl vinyl ethers in the presence of acids $\left(\mathrm{CF}_{3} \mathrm{COOH}, 130^{\circ} \mathrm{C}\right)$ to form Markovnikov adducts. ${ }^{40,41}$ 
Therefore, we limit the review mostly with recent strides in the base-catalyzed and freeradical additions of phosphines and phosphine chalcogenides, yet recently uncommon addends, to the double and triple carbon-carbon bonds.

\subsection{Nucleophilic addition of phosphines and phosphine chalcogenides to alkenes}

2.1.1 Phosphine. Nucleophilic addition of phosphine to the double carbon-carbon bond in the presence of bases was first described by Rauhut et $a l^{42,43}$ and later by King et al. ${ }^{44-52}$ for the alkenes with strong electron-withdrawing substituents. All these works are discussed in detail in a review. ${ }^{4}$

Later, ${ }^{53,54}$ it has been shown that superbasic systems allows hydrophosphination of weakly electrophilic double bonds of aryl- and hetarylethenes with phosphine to synthesize previously unknown or difficult-to-prepare secondary or tertiary phosphines. ${ }^{53-61}$ In these processes, instead of pure phosphine, a phosphine-hydrogen mixture generated from red phosphorus suspensions in organic solvents (dioxane, toluene) under the action of aqueous $\mathrm{KOH}^{53}$ (or $\mathrm{NaOH}$ ) was used. Phosphine thus obtained was successfully utilized in hydrophosphination reactions without further isolation or purification. ${ }^{53-61}$

Thus, bis(2-arylethyl)- and bis(2-hetarylethyl)phosphines (1a-i) were selectively synthesized (Scheme 1) in 60-80\% yield upon slow addition of alkene to a heated $\left(45-60^{\circ} \mathrm{C}\right)$ $\mathrm{KOH}-\mathrm{DMSO}$ suspension while passing the phosphine-hydrogen mixture through reaction mixture. ${ }^{53,54,56-58,60,61}$ Complete and selective aryl(hetaryl)ethylation of phosphine with styrene and vinylpyridines was accomplished (Scheme 1 ) at $95-98^{\circ} \mathrm{C}$ and $67-70^{\circ} \mathrm{C}$, correspondingly, in the KOH-DMSO system with additional introduction of the alkenes to reaction mixture at the end of the process (after the phosphine feeding was stopped) to give tris(2-phenylethyl)- (2a) and tris(2-pyridylethyl)phosphines (2b-d) in $65-76 \%$ yield. ${ }^{58-60}$ 


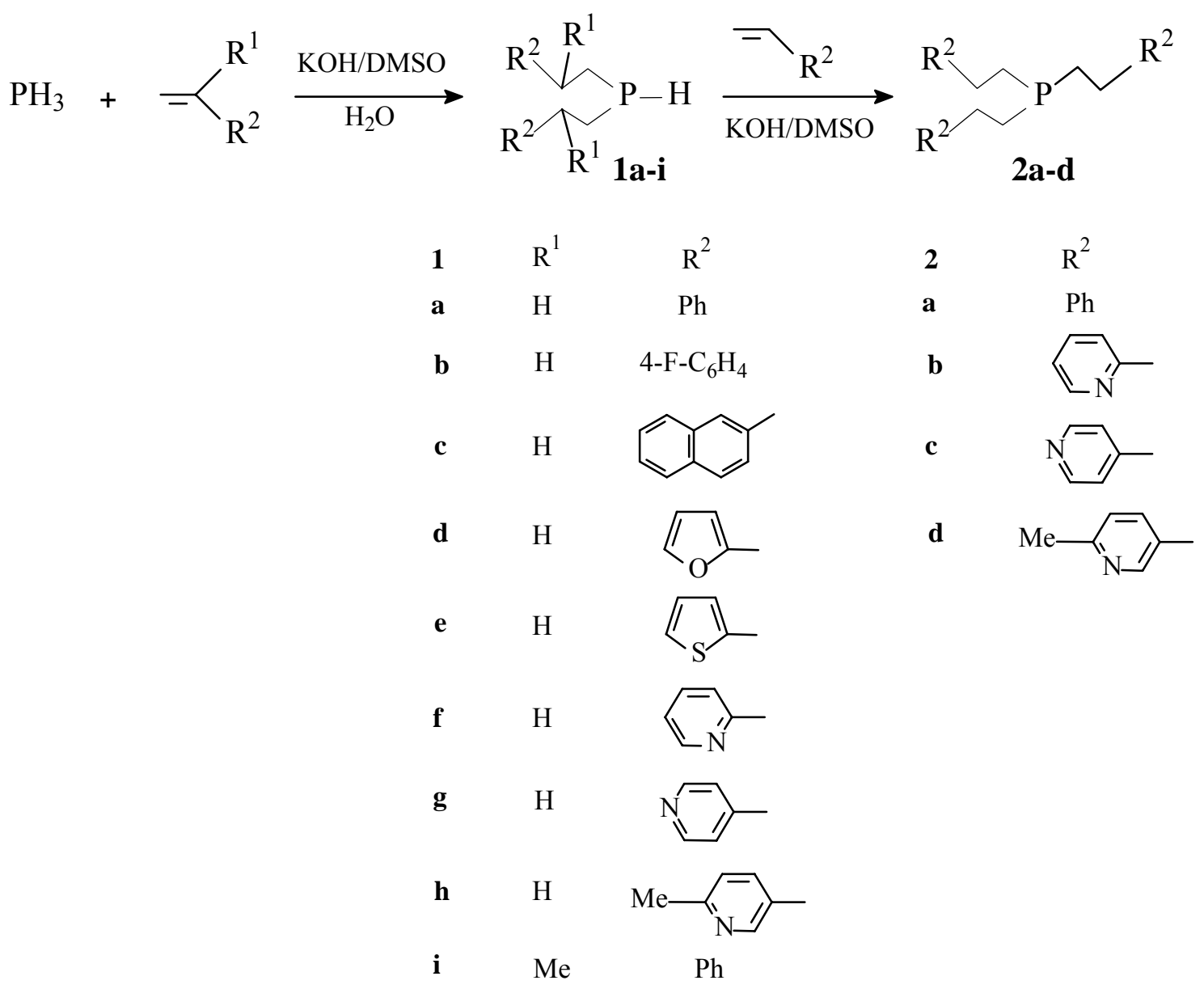

\section{Scheme 1}

At a lower temperature $\left(30-40^{\circ} \mathrm{C}\right)$ corresponding primary phosphines are formed in 20$24 \%$ yield. Still, the major products (up to 60\%) under these conditions remain diorganylphosphines. ${ }^{55,58}$

2.1.2 Primary and secondary phosphines and phosphine chalcogenides. Unlike $\mathrm{PH}_{3}$, which requires a base catalyst for its addition even to strongly electrophilic alkenes, ${ }^{42-52}$ primary and secondary phosphines ${ }^{62-65}$ and phosphine oxides ${ }^{66-70}$ are capable of adding to electron-deficient alkenes (nitroethenes, ${ }^{64}$ fluorosulfonylethene, ${ }^{65}$ acrylonitriles, ${ }^{62,} 63$ organylacrylates, ${ }^{62,} 69,70$ vinylphosphine oxides ${ }^{66-68}$ ) without catalyst, thus providing an atom-economic and ecologically benign synthetic rout to various functionalized phosphines and phosphine oxides. Phosphine oxides bearing unsaturated alkenyl and alkynyl radicals are more active in these processes. ${ }^{69,70}$

Noticeably, the non-catalyzed addition of secondary phosphine oxides and phosphine sulfides to acroleine and its derivatives proceeds at the carbonyl group with the double bond remained intact to give corresponding unsaturated hydroxyl-containing tertiary phosphine oxides and sulfides. ${ }^{71}$, 72 
In the presence of bases addition of organic phosphines ${ }^{47-52,65,73-77}$ and phosphine oxides ${ }^{68,78-90}$ to electron-deficient double bonds results mainly in corresponding tertiary phosphines and phosphine oxides in $27-93 \%$ yield.

Phosphine 3 and phosphine oxide 4 were synthesized through hydrophosphination of divinylsulfone (Scheme 2) under mild conditions (room temperature, KOH-dioxane) in high yield. $^{88}$
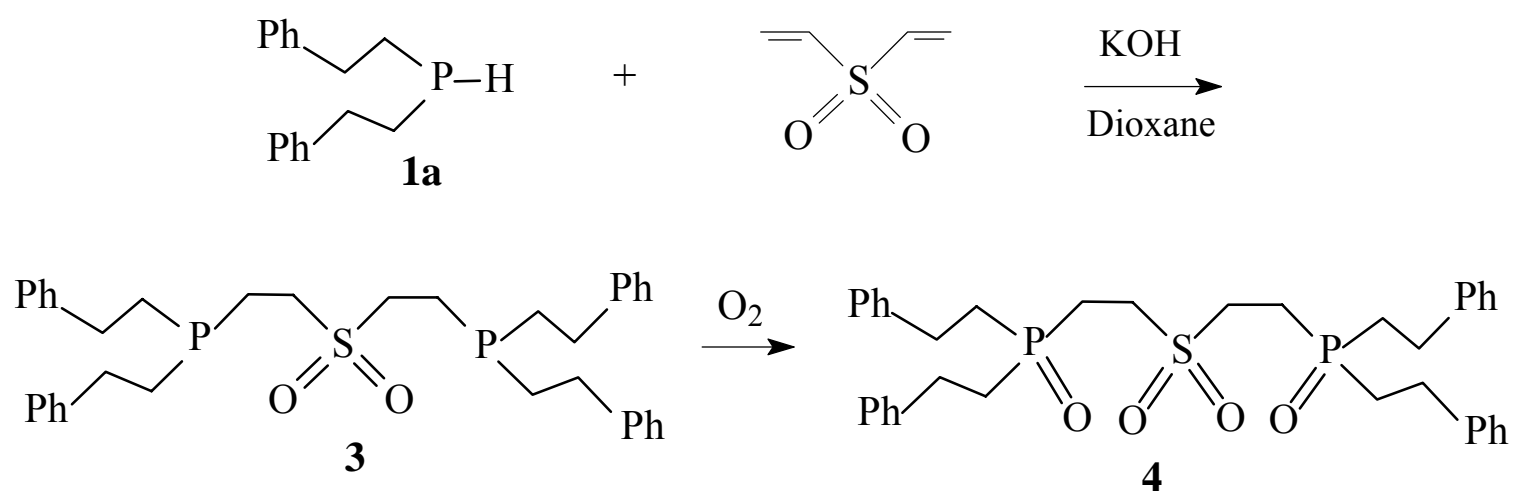

\section{Scheme 2}

Under analogous conditions, secondary bis(2-phenylethyl)- and bis(2phenylpropyl)phosphine oxides $(\mathbf{5 a}, \mathbf{b})$ react with vinylsulfoxides, ${ }^{89}$ divinylsulfoxide $^{90}$ and divinylsulfone ${ }^{88}$ to form corresponding functionalized tertiary phosphine oxides 6 or diphosphine oxides 4, 7 in high yield (Scheme 3).

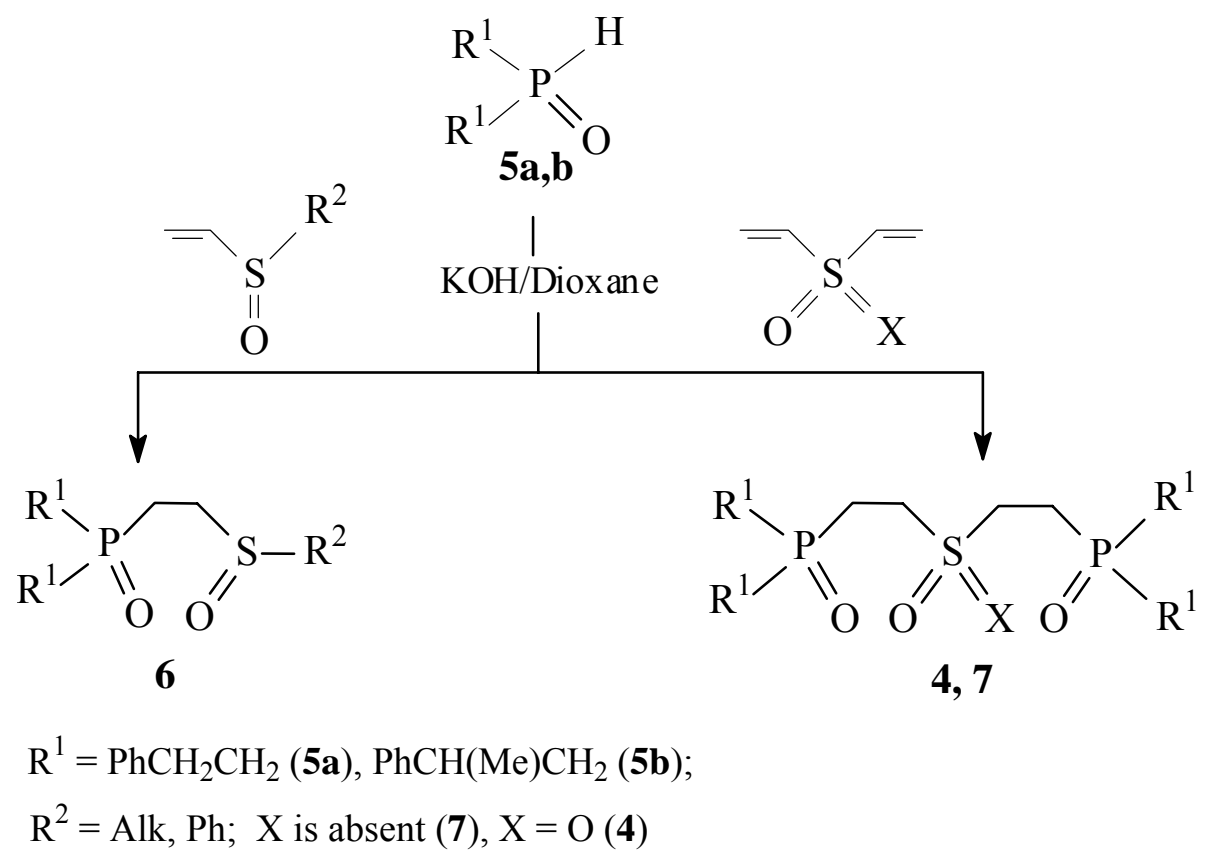

\section{Scheme 3}


At a higher temperature (over $50^{\circ} \mathrm{C}$ ), along with the adducts $4,6,7$, the reaction also gives diorganylvinylphosphine oxides as a result of desulfinylation or desulfonylation of the addition products. ${ }^{88-90}$

Recently, first examples of facile hydrothiophosphorylation of organyl vinyl sulfoxides were described. $^{91}$ Nucleophilic addition of secondary phosphine sulfides to organyl vinyl sulfoxides (KOH-THF, room temperature) proceeds chemo- and regioselectively to give corresponding bis(2-organylethyl)[2-(organylsulfinyl)ethyl]phosphine sulfides in high isolated yield (Scheme 4).

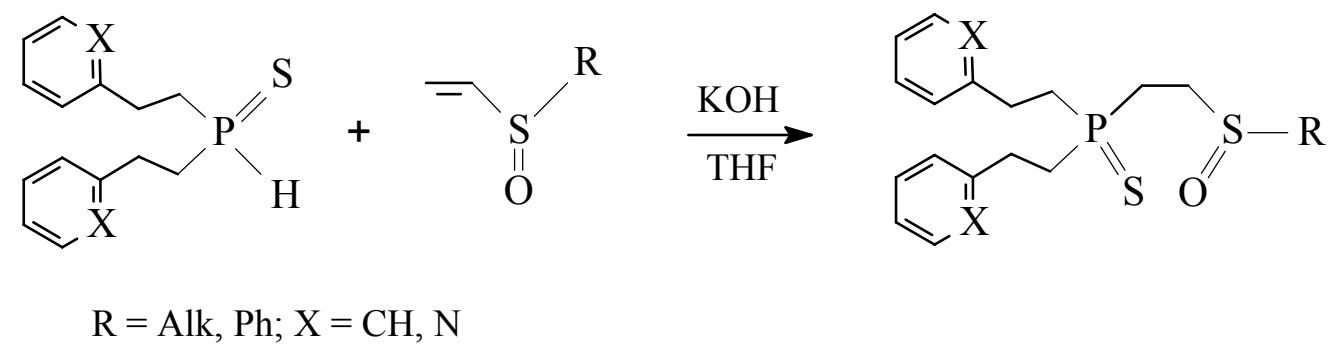

\section{Scheme 4}

Hydrophosphination and hydrophosphorylation of such weakly electrophilic alkenes as styrene, ${ }^{92-94}$ 2-vinylnaphthalene ${ }^{61}$ and vinylpyridines ${ }^{94}$ became possible due to superbase catalytic systems. Thus, 2-phenylpropylphosphine reacts with 4-vinylpyridine ${ }^{94}$ in a $\mathrm{KOH}-$ DMSO suspension to give corresponding tertiary phosphine 8 with chiral carbon (Scheme 5). In the case of the reaction of 2-phenylpropylphosphine with sterically hindered 2-vinylnaphthalene, the process stops at the stage of the formation of secondary phosphine 9 (Scheme 5). ${ }^{61}$

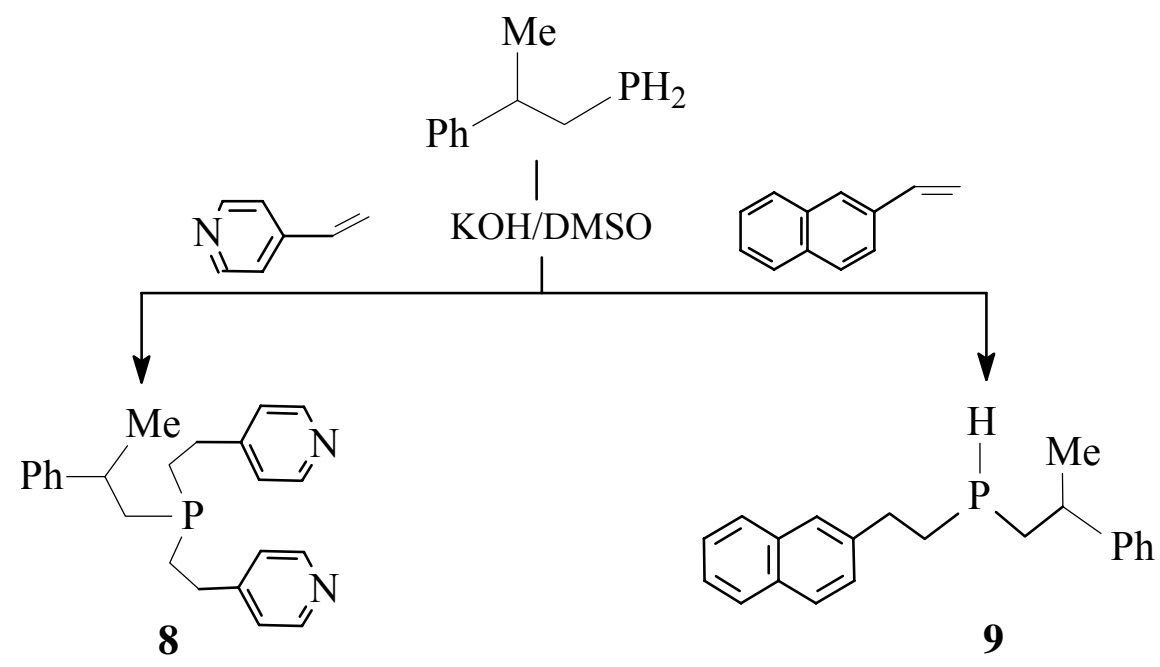

\section{Scheme 5}


Under similar conditions, secondary phosphines 1a,f,h, 9, diphenyl-, bis(3-fluorophenyl)-, bis(4-fluorophenyl), bis(3-trifluoromethylphenyl)phosphines (10a-d), as well as phosphine oxide 5a, diphenyl- and bis[2-(2-methyl-5-pyridyl)ethyl]phosphine oxides (11a,b) add to styrene, ${ }^{60,61,}$ 92-94 and vinylpyridines ${ }^{94}$ to form 2-aryl- and 2-pyridylethyldiorganylphosphines 12a-h or phosphine oxides 13a-c (the yields are 47-95\%) (Scheme 6), prospective building blocks for design of complex-forming luminophores, ${ }^{32,38} P, N$-chelating ligands ${ }^{37}$ and flame retardants. ${ }^{13,} 33$

12a

\section{Scheme 6}

Later, another superbase, $t$-BuOK-DMSO, was used for hydrophosphination and hydrophosphorylation of alkenes. ${ }^{86,87}$ The authors successfully reproduced the reactions with styrene, ${ }^{92-94}$ vinylpyridines ${ }^{94}$ and vinyldiphenylphosphine, ${ }^{47}$ and extended the set of alkenes over vinyltriphenylsilane $^{86}, \quad 1$-vinylimidazole (in the $t$-BuOK-toluene system) ${ }^{95}$ and vinylphenylsulfide. ${ }^{86}$ The latter two reactions are, to the best of our knowledge, the first 
examples of nucleophilic addition to such electron-rich double bonds. Unfortunately, the paper ${ }^{86}$ does not contain any data proving the structures of the compounds obtained.

The system KOH-DMSO also allowed the reaction of 3-thiolene-1,1-dioxide (14a) with primary phosphines ${ }^{96}$ and secondary phosphine chalcogenides $5 \mathbf{a}, \mathbf{1 5 ^ { 9 7 , }}{ }^{98}$ to be carry out. The corresponding adducts were synthesized in high yield. Without $\mathrm{KOH}$ or under radical conditions $\left[65^{\circ} \mathrm{C}, \quad 6 \mathrm{~h}, \quad\right.$ azabisisobutyronitrile $\left.(\mathrm{AIBN})\right]$, neither hydrophosphination nor hydrophosphorylation occurs, thus confirming the nucleophilic character of this addition, which, presumably, proceeds via the formation of intermediate 2-thiolene-1,1-dioxide (14b) (Scheme 7). ${ }^{97,98}$

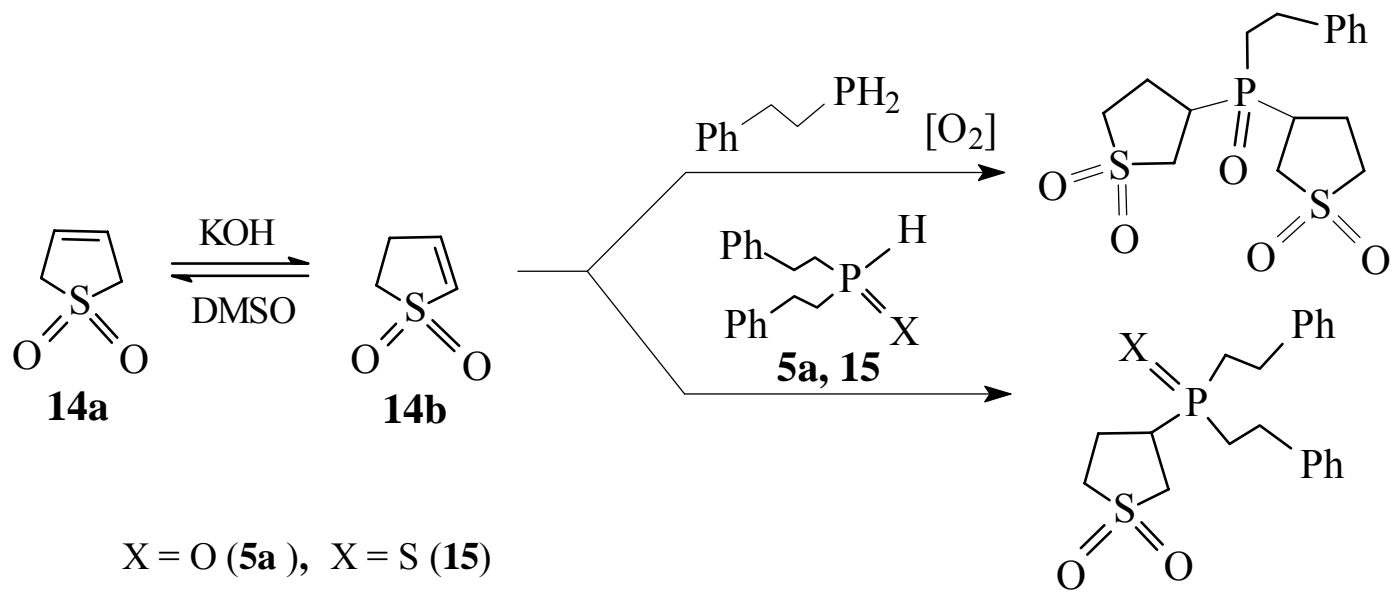

\section{Scheme 7}

\subsection{Radical addition of phosphines and phosphine chalcogenides to alkenes}

2.2.1 Phosphine. Addition of phosphine to alkenes under radical conditions (organic peroxides, AIBN, UV irradiation) was published mainly as patents and discussed in a review. ${ }^{4}$ Representative recent investigations are the synthesis of limonene-derived chiral phosphines ${ }^{99}$ and polyfunctional tertiary phosphines and phosphine oxides from vinylsulfides. ${ }^{100}$ The use of phosphine-hydrogen mixture ${ }^{53}$ generated in situ from elemental phosphorus in the latter case demonstrates applicability of this available phosphorylating reagent also for free-radical addition reactions. $^{100}$

Thus, the phosphine-hydrogen mixture generated from red phosphorus in the system $\mathrm{KOH}-$ toluene- $\mathrm{H}_{2} \mathrm{O}$, reacts readily with vinyl sulfides under free-radical conditions (dioxane, AIBN, 65$70^{\circ} \mathrm{C}$, atmospheric pressure) to give regiospecifically anti-Markovnikov adducts, tris[2(organylthio)ethyl]phosphines (16) (Scheme 8). ${ }^{100}$ The latter easily oxidize by air during their isolation and purification on $\mathrm{Al}_{2} \mathrm{O}_{3}$ giving a 56-83\% yield of tris[2-(organylthio)ethyl]phosphine oxides (17) (Scheme 8). 


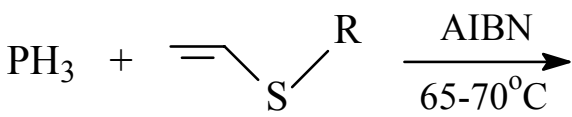

$\mathrm{R}=\mathrm{Et}, \mathrm{Pr}, \mathrm{Bu}, \mathrm{Ph}$

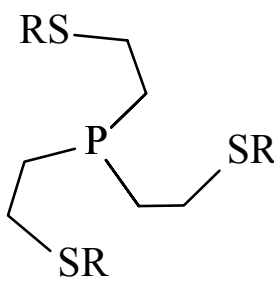

16<smiles>[R5]CCP(=O)(CC[R5])CC[R5]</smiles>

17

\section{Scheme 8}

2.2.2 Primary and secondary phosphines. Addition of primary and secondary phosphines to alkenes (linear unsubstituted alkenes ${ }^{101}$ with terminal double bonds and, less often, internal ones, as well as cycloalkenes, ${ }^{101}$ aryl- and hetarylalkenes, ${ }^{101,102}$ dienes, ${ }^{101}$ vinyl $^{40,41,101}$ and divinyl ${ }^{103}$ ethers, vinylsulfides, ${ }^{104,} 105$ vinyl phosphines, ${ }^{106,107}$ unsaturated organohalides, ${ }^{108}$ acrylic acid derivatives $^{101,} 109$ etc) under free-radical conditions is widely used in organophosphorus synthesis. ${ }^{110}$ This pathway allows one to obtain phosphines with hydrophilic substituents, ${ }^{62,101,}$ 102, 109, 111, 112 including water-soluble phosphines, di- and polyphosphines, ${ }^{106,107,113}$ polydentate $P, N-{ }^{62,101,102,107,111,114} \mathrm{P}, \mathrm{O}_{-},{ }^{62,101-103,111} \mathrm{P}, \mathrm{S}-{ }^{104,},{ }^{105,107} \mathrm{P}, \mathrm{Se}-{ }^{105}$ and $\mathrm{P}, \mathrm{Si}_{-}{ }^{115,116}$ ligands.

Hydrophosphination of vinyl ethers, ${ }^{41}$ vinyl sulfides ${ }^{105}$ and vinyl selenides ${ }^{105}$ with secondary phosphines 1a,g, 18, prepared from elemental phosphorus and electrophiles in superbase systems, ${ }^{53,117}$ readily proceeds under UV irradiation or in the presence of AIBN at 65$70^{\circ} \mathrm{C}$ to form the corresponding phosphines 19 (Scheme 9) in nearly quantitative yields. ${ }^{41,105}$

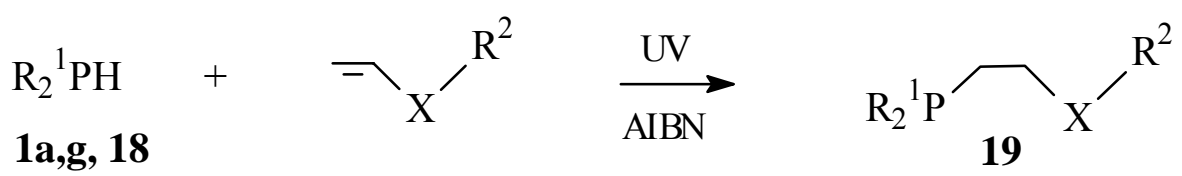

$$
\mathrm{R}^{1}=\mathrm{PhCH}_{2} \mathrm{CH}_{2} \text { (1a), }
$$

\section{Scheme 9}

Novel optically active polyfunctional tertiary phosphines 20a,b have been synthesized in high yield by the hydrophosphination of chiral vinyl ether 21 (prepared from diacetone- $D$ glucose and acetylene) with secondary phosphines 1a, 18, proceeding regiospecifically in the presence of AIBN at $65-70^{\circ} \mathrm{C}$ (Scheme 10). ${ }^{118}$ 


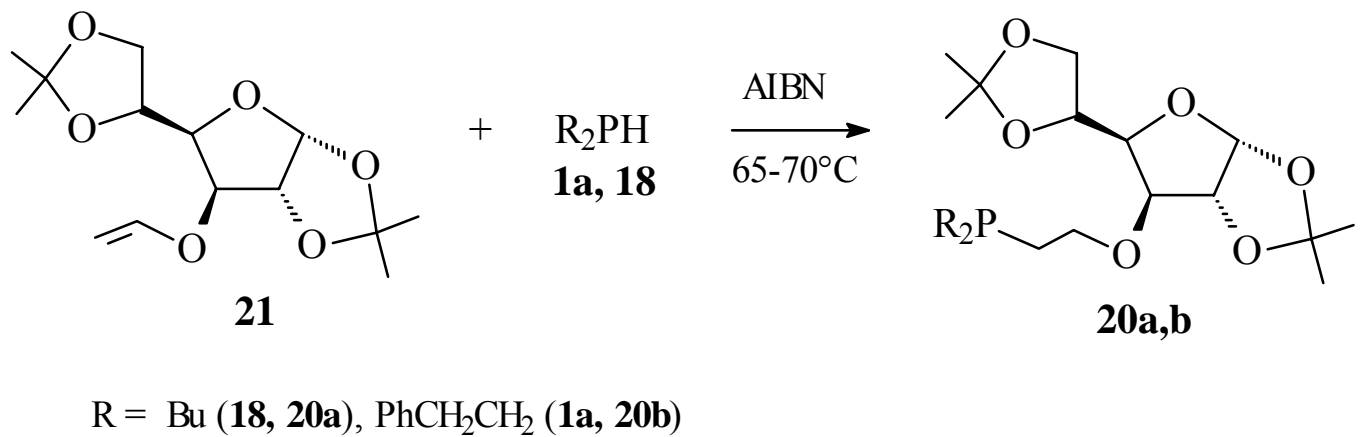

\section{Scheme 10}

With air or elemental sulfur the phosphines 20a,b quantitatively oxidize to the corresponding phosphine oxides or phosphine sulfides, respectively. ${ }^{118}$ Polydentate phosphines, phosphine oxides and phosphine sulfides thus obtained, containing protected hydroxy functionalized tetrahydrofuran and dioxolane moieties, are promising chelating ligands for metal complex catalysts for asymmetric synthesis.

Recently, first examples of the hydrophosphinations of available ${ }^{24,} 25 \mathrm{~N}$-vinyl- and $\mathrm{N}$ isopropenylpyrroles have been reported. ${ }^{119,120}$

Secondary phosphines 1a,f, 18 add to $N$-vinylpyrroles regio- and chemospecifically in the presence of AIBN at $65-70^{\circ} \mathrm{C}$ or under UV irradiation to form almost quantitatively the corresponding tertiary diorganyl-2-(1-pyrrolyl)ethylphosphines (22) (Scheme 11) ${ }^{119}$ prospective polydentate $P, N$-ligands. ${ }^{87,121-123}$

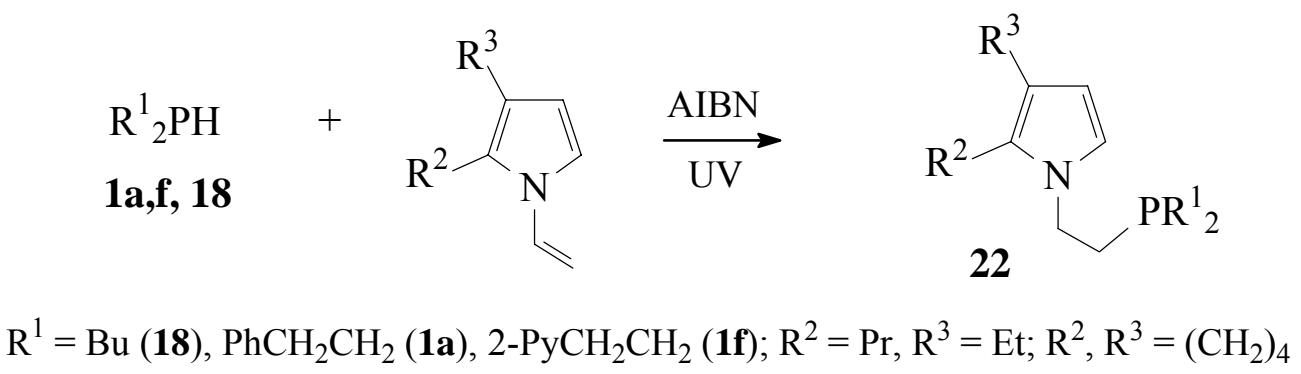

\section{Scheme 11}

Free-radical addition of secondary phosphines 1a,f, 23 to 1-isopropenylpyrroles (AIBN, $\left.65^{\circ} \mathrm{C}\right)$ also proceeds with $100 \%$ regioselectivity to give diorganyl-2-(1pyrrolyl)propylphosphines (24) in 89-92\% isolated yields (Scheme 12). ${ }^{120}$ 


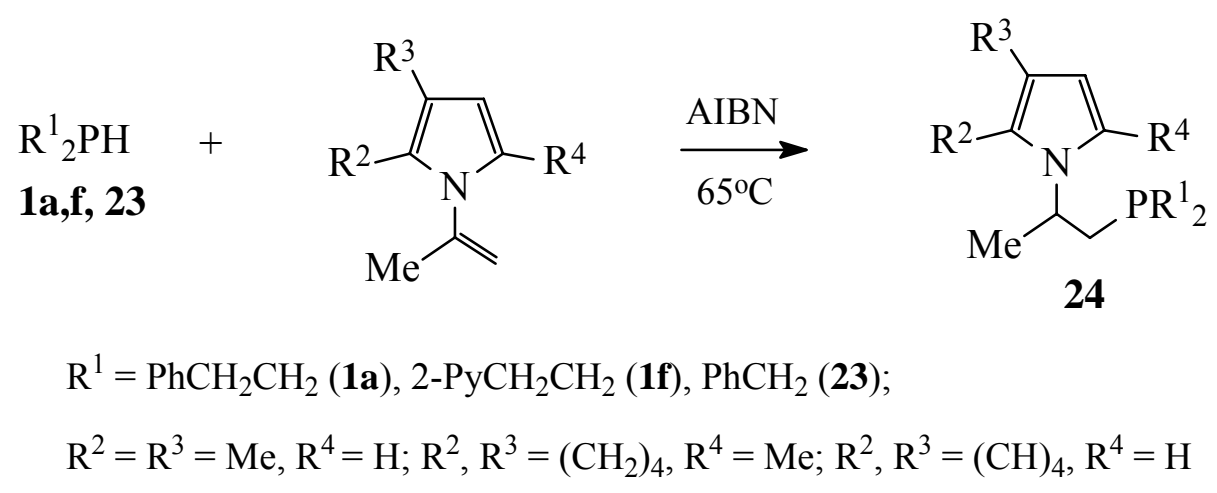

\section{Scheme 12}

2.2.3 Secondary phosphine chalcogenides. Hydrophosphorylation ${ }^{79,}$ 124-130 and hydrothiophosphorylation ${ }^{131-135}$ of alkenes proceeding under radical initiation and giving antiMarkovnikov adducts are scarcely studied.

Recently, chemo- and regiospecific synthesis of 2-alkoxyethyl(di-2-phenylethyl)phosphine sulfides 25 in practically quantitative yield (92-98\%) was realized by hydrothiophosphorylation of alkyl vinyl ethers with $P, S$-ambident ${ }^{136}$ bis(2-phenylethyl)phosphine sulfide (15) in the presence of AIBN $\left(60-65^{\circ} \mathrm{C}, 5 \mathrm{~h}, \mathrm{THF}\right)\left(\right.$ Scheme 13). ${ }^{134}$

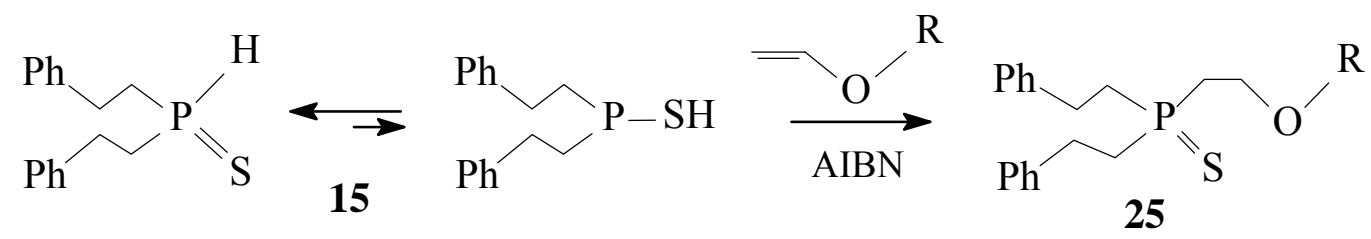

$$
\mathrm{R}=\mathrm{Et}, \mathrm{Bu}, i-\mathrm{Bu}
$$

\section{Scheme 13}

The chemo- and regioselective addition of secondary phosphine sulfides to alkyl vinyl ethers contributes to better understanding the reactivity of the both classes of compounds and offers a facile straightforward route to potent cocatalysts and "hemilabile" ligands ${ }^{137}$ (e.g., triphenylphosphine sulfide is more effective ligand for palladium-catalyzed bisalkoxycarbonylation of olefins than triphenylphosphine ${ }^{138}$ ).

Later, free-radical addition of diphenylphosphine sulfide to butyl vinyl ether was realized using $\mathrm{Et}_{3} \mathrm{~B} / \mathrm{O}_{2}$ as the initiator. ${ }^{135}$ Apart from alkenes with electron-rich double bonds, the authors also used a set of alkenes with electron-poor double bonds to prepare phosphine sulfides 26 (Scheme 14). 
<smiles>COC(=O)CCP=S=P</smiles>

26a<smiles>NC(=O)CCP=S</smiles>

26d<smiles>COC(=O)C(C)CP=S</smiles>

26b<smiles>O=C1CC(P=S)C(=O)N1c1ccccc1</smiles>

26e<smiles>N#CCC[PH]([O-])=S</smiles><smiles>C[C@H]1C(=O)N(c2ccccc2)C(=O)C1P=S</smiles>

$26 f$

\section{Scheme 14}

\section{Nucleophilic addition of phosphines and phosphine chalcogenides to alkynes}

Addition of P-H reagents to acetylenes ${ }^{4,47,93,101,109,139-163}$ is a convenient and atom-economic method of the $\mathrm{C}-\mathrm{P}$ bond formation and the simplest route to unsaturated phosphines. At the same time, this field still remains poorly explored and existing publications are mostly related to nucleophilic addition of phosphines and phosphine chalcogenides. $4,47,93,139-142,144,146-149,151-153$, $155-163$

\subsection{Phosphine}

The data on the addition of phosphine to the triple carbon-carbon bond are limited to reports concerning phosphorylation of aryl- and hetarylalkynes in the presence of superbase. ${ }^{4,153,155}$ The reaction proceeds under mild conditions $\left(55-60^{\circ} \mathrm{C}\right.$, atmospheric pressure) upon passing phosphine-hydrogen mixture generated from red phosphorus and potassium hydroxide in aqueous dioxane through the reaction mixture to give stereoselectively tris(Z-2organylethenyl)phosphines (27) in 60-80\% yields (Scheme 15). ${ }^{153,155}$ The stereodirection of these reactions agrees with the common trans-addition scheme. ${ }^{25,34}$

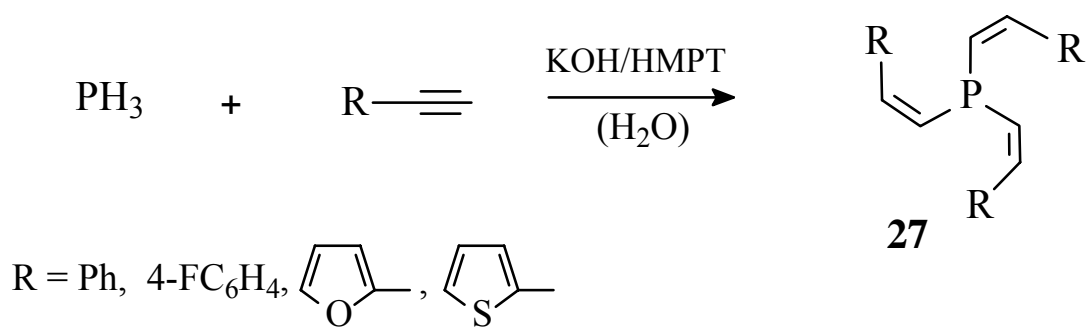

Scheme 15 


\subsection{Primary phosphines}

Similarly to phosphine, primary phosphines react with acetylenes according to the nucleophilic monoaddition mechanism to form $Z$-ethenylphosphines. With weakly electrophilic acetylenes, these reactions, as a rule, require strong bases to proceed.

Phenylphosphine reacts with di(alkynyl)sulfides under the action of base system $\mathrm{LiNH}_{2}$ $\mathrm{NH}_{3}$ to afford 4-phenyl-4H-1,4-thiaphosphinines (Scheme 16). ${ }^{144}$

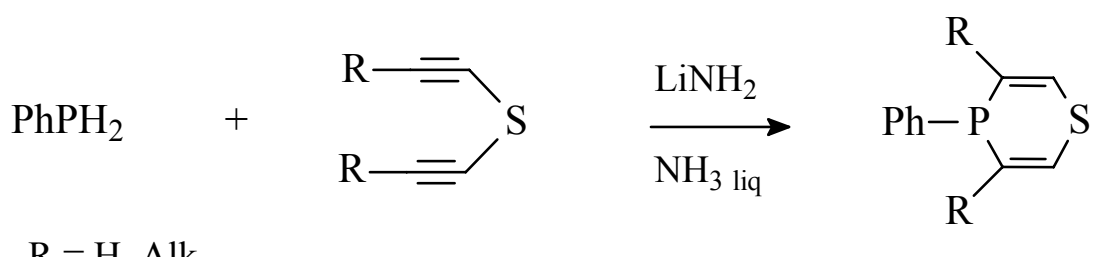

\section{Scheme 16}

Primary alkyl- and arylalkylphosphines add to phenylacetylene in the KOH-DMSO suspension $\left(60^{\circ} \mathrm{C}, 1-4 \mathrm{~h}\right)$ giving predominantly or exclusively $Z, Z$-isomers of bis(2phenylethenyl)organylphosphines (28) (Scheme 17) in good yield (up to 81\%). ${ }^{159}$

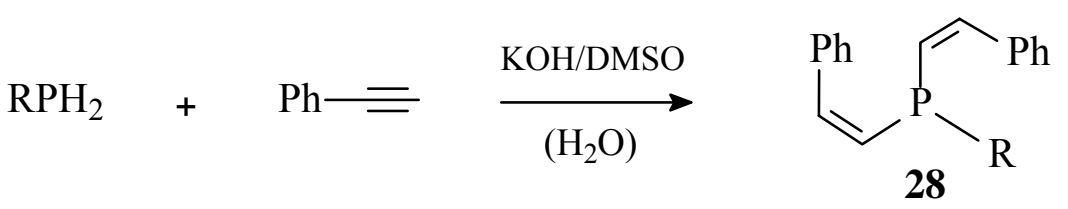

$$
\mathrm{R}=\mathrm{C}_{6} \mathrm{H}_{13}, \mathrm{PhCH}_{2} \mathrm{CH}_{2}, \mathrm{PhCH}(\mathrm{Me}) \mathrm{CH}_{2}
$$

\section{Scheme 17}

Activated phenylcyanoacetylene reacts with alkylphosphines under milder conditions ( $\mathrm{KOH}$-dioxane suspension, $20-22^{\circ} \mathrm{C}$ ) to afford, depending on the reactant ratio, either secondary 29 or tertiary $\mathbf{3 0}$ phosphines of Z-configuration in the yield of $70-91 \%$ (Scheme 18). ${ }^{160}$ According to ESR and UV data, the addition involves a single electron transfer. ${ }^{160}$

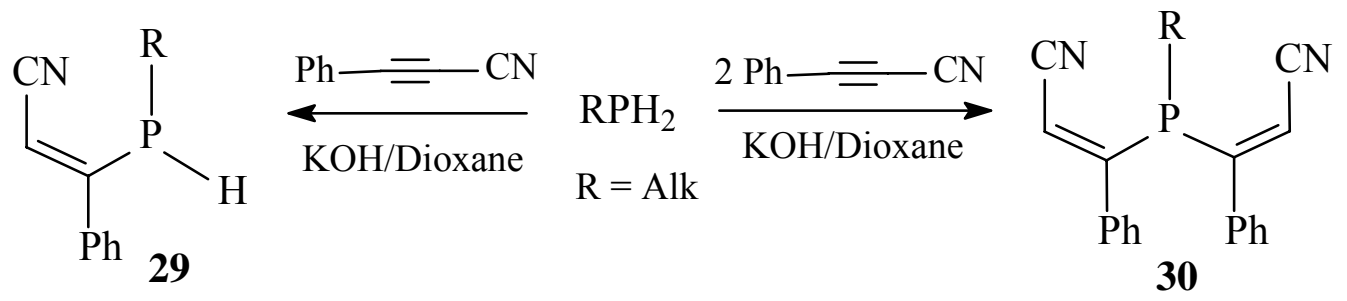

\section{Scheme 18}


Organic phosphines were also reported to be capable of adding to arylacetylenes without catalyst, but a high temperature (over $100^{\circ} \mathrm{C}$ ) and long reaction time were required. ${ }^{140,141,151}$ Thus, reaction of 2,6-bis(trifluoromethyl)phenyl]phosphine with phenylacetylene $\left(100-110^{\circ} \mathrm{C}, 40\right.$ h) gave $E$ - and $Z$-isomers of secondary [2,6-bis(trifluoromethyl)phenyl](styryl)phosphine in a ratio of $3 / 2$ (59\% yield) (Scheme 19). ${ }^{151}$
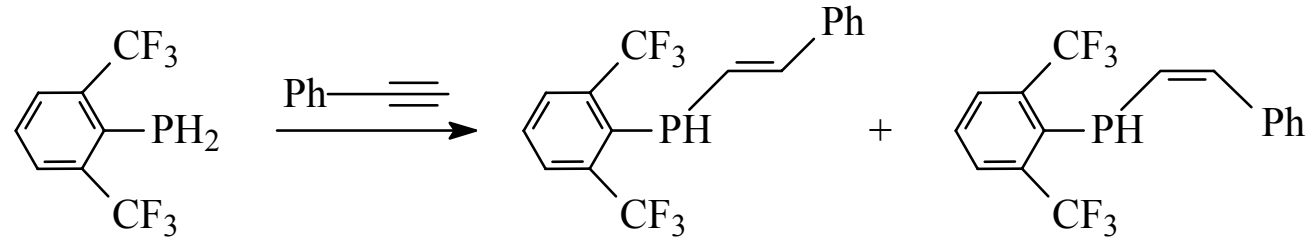

\section{Scheme 19}

\subsection{Secondary phosphines}

Unlike primary phosphines, secondary phosphines add to acetylenes with strong electronwithdrawing substituents (cyanoacetylene, ${ }^{146}$ phenylcyanoacetylene, ${ }^{157,}{ }^{160}$ 4-hydroxy-4-methyl2-pentynenitrile, ${ }^{160,162}$ methyl 2-propynoate, ${ }^{147}$ hexafluoro-2-butyne ${ }^{139}$ ) without catalysts.

Dialkylphosphines react with cyanoacetylene to afford exclusively or predominantly $Z$-isomers of the corresponding alkenes $\mathrm{Alk}_{2} \mathrm{PCH}=\mathrm{CHCN} .{ }^{146}$

The reaction of bis(2-phenylethyl)- and bis(2-phenylpropyl)phoshines (1a,i) with phenylcyanoacetylene proceeds with the same stereodirection to give mainly monoadducts 31a,b, ${ }^{157}$ though in the case of $\mathbf{1 i}$ a considerable amount of $E$-isomer 32b is formed (Scheme 20) that is explained by the competition of trans- and cis-addition to triple bond owing to steric hindrance. According to ESR and UV data, the reaction involves a single electron transfer. ${ }^{157}$

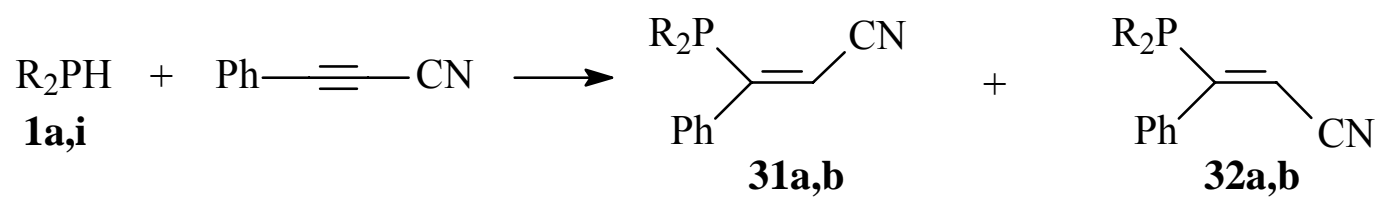

a: $Z / E=19 / 1, \mathbf{b}: Z / E=3 / 2$

$\mathrm{R}=\mathrm{PhCH}_{2} \mathrm{CH}_{2}(\mathbf{1 a}, 31 \mathbf{a}, 32 \mathbf{a}), \mathrm{PhCH}(\mathrm{Me}) \mathrm{CH}_{2}(\mathbf{1 i}, \mathbf{3 1} \mathbf{b}, \mathbf{3 2 b})$

\section{Scheme 20}

An easy stereocontrolled access to functionalized tertiary phosphines $\mathbf{3} 3$ of $Z$-configuration proves to be the addition of dibutyl-, bis(2-phenylethyl)- and bis[2-(2-pyridyl)ethyl]phosphines $(\mathbf{1 8}, \mathbf{1 a}, \mathbf{f})$ to 4-hydroxy-4-methyl-2-pentynenitrile (Scheme 21). ${ }^{160,162}$ 


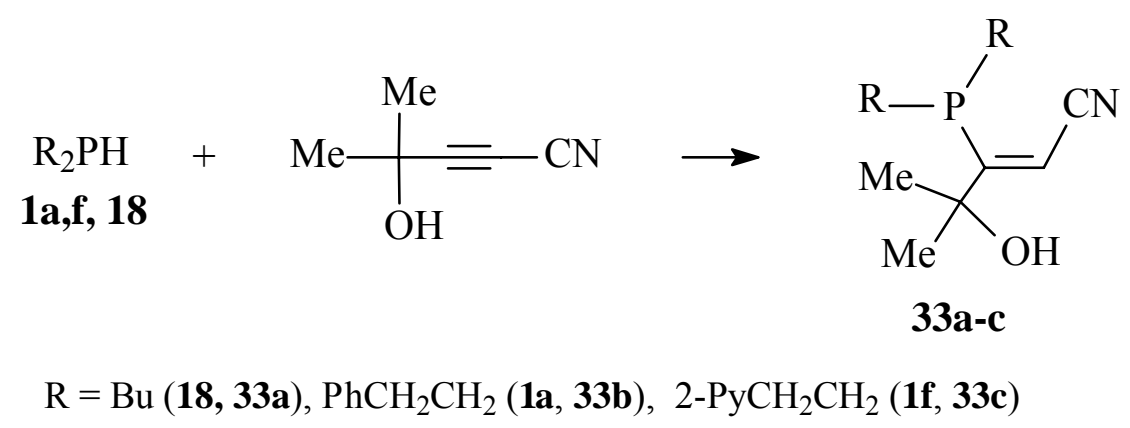

\section{Scheme 21}

Only $E$-isomers of ethenylphosphines $\mathrm{Alk}_{2} \mathrm{PCH}=\mathrm{CHCO}_{2} \mathrm{Me}$ are formed in the reaction of dialkylphosphines with methyl 2-propynoate. ${ }^{147}$ Authors explain this fact by easy isomerization of the intermediate carbanion.

Non-catalyzed interaction of diphenylphosphine (10a) with dimethyl 2-butynedioate reveals the effect of second strong electron-withdrawing group, which activates double bond of the intermediate monoadduct. As a result, the reaction affords the saturated $\alpha, \beta$-diadduct 34 (Scheme 22). ${ }^{142}$

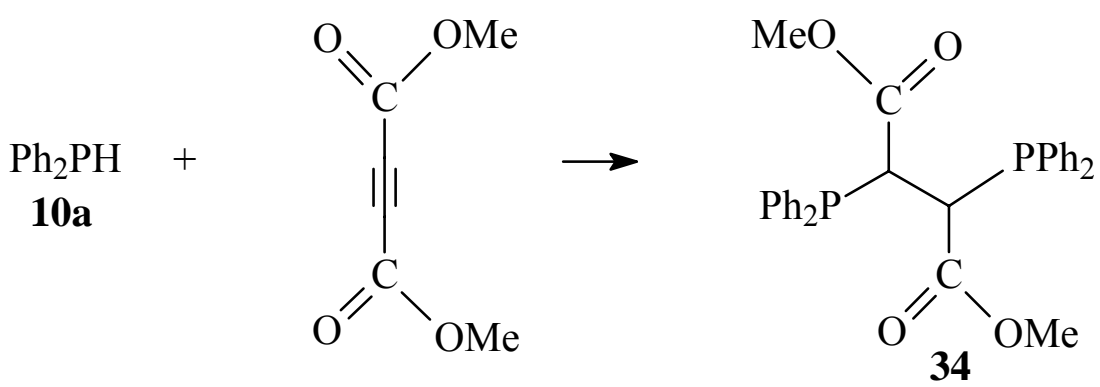

\section{Scheme 22}

These reactions of phosphines with activated acetylenes (Schemes 19-22) represent a new general atom-economic approach to the synthesis of versatile reactive building blocks for organic synthesis and prospective polydentate and amphiphilic ligands for design of metal complex catalysts. $^{77,164}$

With weakly electrophilic acetylenes, addition of secondary phosphines requires strong bases or high temperature to proceed.

Prolonged heating $\left(100^{\circ} \mathrm{C}, 4\right.$ days $)$ of diphenylphosphine and diphenylacetylene afforded $E$-isomer of the corresponding monoadduct $\mathrm{Ph}_{2} \mathrm{PC}(\mathrm{Ph})=\mathrm{CHPh} .{ }^{141}$ It seems that the formation of $E$-isomers in this addition ${ }^{141}$ as well as in the reaction presented in Scheme $19^{151}$ is thermodynamically controlled, i.e., under the reaction conditions $Z$-adduct isomerizes to the $E$ form. 
Diphenylphosphine with diphenyl(ethynyl)phosphine $\mathrm{Ph}_{2} \mathrm{PC} \equiv \mathrm{CH}$ in the presence of $\mathrm{PhLi}$ furnishes $E-\mathrm{Ph}_{2} \mathrm{PCH}=\mathrm{CHPPh}_{2}$ in a $72 \%$ yield. ${ }^{47}$ The $E$-isomer is likely to be formed owing to sterical factors.

Diphenylphosphine (10a) adds to arylacetylenes in the presence of strong bases giving arylethenylphosphines 35 of unknown configuration (Scheme 23). ${ }^{93,}{ }^{148}$ From the ${ }^{3} J_{\mathrm{HP}}$ coupling, ${ }^{148}$ one may assume ${ }^{165}$ that the compound $35 \mathrm{c}$ is a $Z$-isomer.

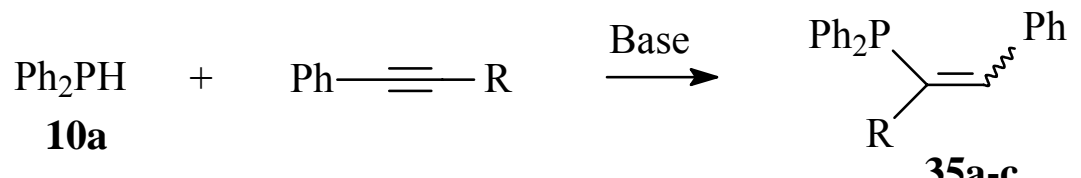

$$
\begin{aligned}
& \mathrm{R}=\mathrm{H}(\mathbf{3 5 a}), \mathrm{Ph}(\mathbf{3 5 b}), \mathrm{PhCH}_{2} \text { (35c) } \\
& \text { Base - KOH/DMSO, } t \text {-BuOK }
\end{aligned}
$$

\section{Scheme 23}

Later, reaction of diphenylphosphine with diarylacetylenes $\mathrm{RC} \equiv \mathrm{CR}^{1}\left(\mathrm{R}=\mathrm{Ph}, \mathrm{R}^{1}=\mathrm{Ph}, o\right.$ tolyl, $m$-tolyl or 2-biphenyl; $\mathrm{R}=m$-tolyl, $\mathrm{R}^{1}=o$-tolyl, $m$-tolyl) was studied in detail. ${ }^{149,156} \mathrm{In}$ the system $t$-BuOK-THF the reaction yields monoadducts $\mathrm{Ph}_{2} \mathrm{PC}(\mathrm{R})=\mathrm{CHR}^{1}$ and/or diphosphines $\mathrm{Ph}_{2} \mathrm{PCH}(\mathrm{R}) \mathrm{CH}\left(\mathrm{R}^{1}\right) \mathrm{PPh}_{2}$ in a ratio that depends on the reactants ratio and nature of the substituent structure. ${ }^{149,156}$

\subsection{Secondary phosphine chalcogenides}

Addition of secondary phosphine chalcogenides to acetylenes ${ }^{89,93,152,161,163}$ proceeding in the presence of base catalysts usually results in double addition products. Presumably, this occurs due to the strong electron-withdrawing character of phosphoryl or thiophosphoryl group, which activates double bond of monoadducts toward addition of the second phosphine chalcogenide molecule.

Unsubstituted acetylene, as well as alkyl- and arylacetylenes add secondary phosphine oxides in the superbase system KOH-DMSO to give diphosphine oxides 36 (Scheme 24). ${ }^{89,93,152 \text {, }}$ 161

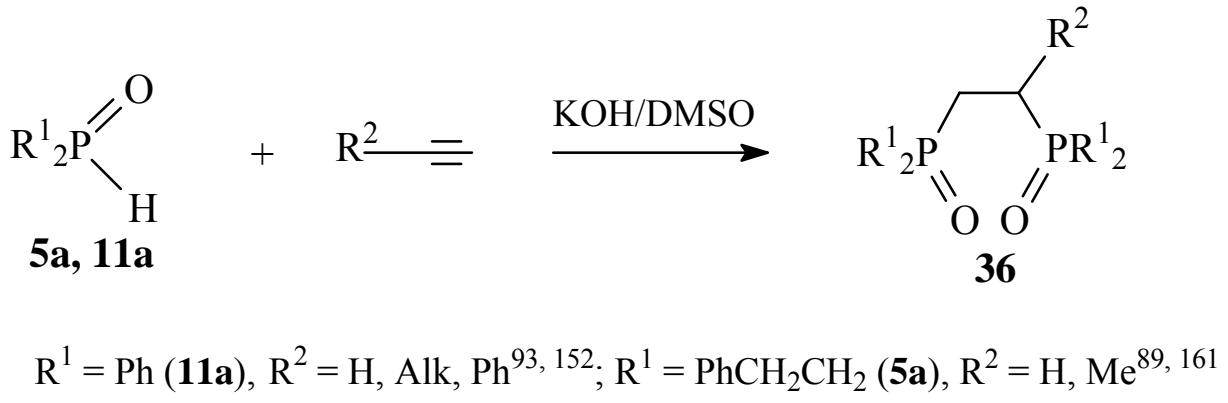

Scheme 24 
Recently, there was found that the reaction of phenylcyanoacetylene with secondary phosphine oxide 5 a and sulfide 15 proceeds under milder conditions (KOH-THF, 22-62 ${ }^{\circ} \mathrm{C}$ ) forming unexpected $\alpha, \beta$-diadducts 37 (Scheme 25). ${ }^{163}$<smiles>[X][PH2+]P</smiles>

5a, 15

$\mathrm{R}=\mathrm{PhCH}_{2} \mathrm{CH}_{2}, \mathrm{X}=\mathrm{O}(\mathbf{5 a}), \mathrm{S}(\mathbf{1 5})$<smiles>[R]P([R])C([C@H](C)P)[PH]([R])([X])[R]([R])([R])[R]</smiles>

37

\section{Scheme 25}

Unusual here is the second stage of the process, addition of phosphine chalcogenides to the $\alpha$-position of intermediate acrylonitrile system. Apparently, this occurs due to the competing electron-withdrawing effect of the added phosphoryl group, which changes the polarization of the double bond contributing the zwitterionic forms $\mathbf{A}$ and $\mathbf{B}$ (Scheme 26).

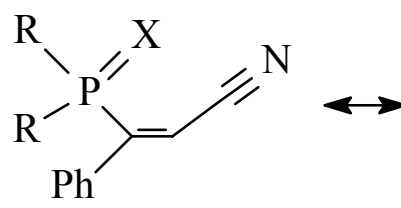

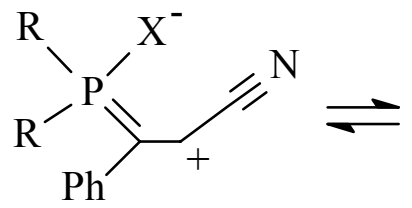

A<smiles>[R][P+]1([R])[X]C(=[N-])C=C1P</smiles>

B

\section{Scheme 26}

Perhaps, this pathway is the only one also because the alternative addition to the $\beta$-carbon is sterically hindered.

$\alpha, \beta$-Acetylenic aldehydes, namely 3-(trialkylsilyl)-, 3-(trialkylgermyl)-2-propynals as well as 2-propynal react with secondary phosphine oxides under mild conditions $\left(-10\right.$ to $\left.22^{\circ} \mathrm{C}\right)$ by carbonyl group only to give corresponding tertiary phosphine oxides in quantitative yield. ${ }^{166}$

Haloacetylenes are usually prone to nucleophilic substitution reactions. ${ }^{167-169}$ However, bis(2-phenylethyl)phosphine oxide (5a) was found to add to alkylthio(chloro)acetylenes (dioxane, 20-22 ${ }^{\circ} \mathrm{C}$ ) in the presence of equimolar amount of $\mathrm{KOH}$ to form regio- and stereoselectively 1-chloro-2-(alkylthio)vinyl(diphenylethyl)phosphine oxides (38) (Scheme 27) of Z-configuration (the yield is $78-85 \%$ ). ${ }^{158}$ 


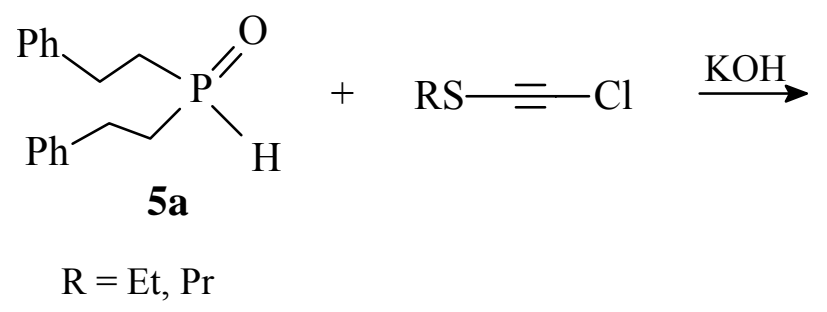

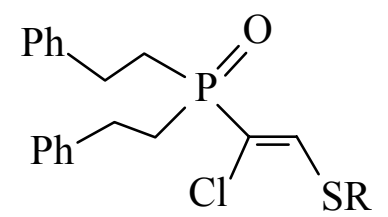

38

\section{Scheme 27}

\section{Conclusions}

In conclusion, nucleophilic and free-radical additions of now readily available phosphines and their chalcogenides to alkenes and alkynes are attracting increasing attention as heavy-metal free and atom-economic syntheses of valuable, and otherwise inaccessible, functionalized phosphines and phosphine chalcogenides.

\section{Acknowledgments}

Financial support of the Russian Foundation for Basic Research (Grant No 04-03-32045) and the Innovation Agency of the Russian Federation (Grant No MK-3775.2004.3) is gratefully acknowledged.

\section{References}

1. Giheany, D. G.; Mitchell, C. M. In The Chemistry of Organophosphorus Compounds; Hartley, F. R. Ed.; Wiley: Chichester, 1990; Vol. 1, p 385.

2. Hudson, H. R. In The Chemistry of Organophosphorus Compounds; Hartley, F. R. Ed.; Wiley: Chichester, 1990; Vol. 1, p 173.

3. Erastov, O. A.; Nikonov, G. N. Funktsional'nozameshchennye Fosfiny i Ikh Proizvodnye (Functional-Substituted Phosphines and Their Derivatives); Nauka: Moscow, 1986.

4. Trofimov, B. A.; Arbuzova, S. N.; Gusarova, N. K. Usp. Khim. 1999, 68, 240 [Russ Chem. Rev. 1999, 68, 215 (Engl Transl)].

5. Lobana, T. S. In The Chemistry of Organophosphorus Compounds; Hartley, F. R. Ed.; Wiley: New York, 1992; Vol. 2, pp 521-5.

6. Noyori, R. Asymmetric Catalysis in Organic Synthesis; John Wiley \& Sons: New York, 1994.

7. Brandsma, L.; Vasilevsky, S. F.; Verkruijsse, H. Application of Transition Metal Catalysts in Organic Synthesis; Springer-Verlag: Berlin, Heidelberg, New York, 1998. 
8. Jacobsen, E. N.; Pfaltz, A.; Yamamoto, H. Comprehensive Asymmetric Catalysis; Springer: Berlin, 1999.

9. Ojima, I. Catalytic Asymmetric Synthesis; 2nd ed.; VCH Pubishers: Weinheim, 2000.

10. Arisawa, M.; Yamaguchi, M. Adv. Synth. Catal. 2001, 343, 27.

11. Faller, J. W.; Wilt, J. C.; Parr, J. Organic. Lett. 2004, 6, 1301.

12. Khalturinsky, N. A.; Popova, T. V.; Berlin, A. A. Usp. Khim. 1984, 53, 326.

13. Malysheva, S. F.; Sukhov, B. G.; Gusarova, N. K.; Shaikhudinova, S. I.; Kazantseva, T. I.; Belogorlova, N. A.; Kuimov, V. A.; Trofimov, B. A. Phosph., Sulf. and Silic. and related elem. 2003, 178, 425.

14. Korovin, V. Yu.; Randarevich, S. B.; Bodaratsky, S. V.; Trachevsky, V. V. Zh. Neorg. Khim. 1990, 35, 2404.

15. Yudelevich, V. I.; Komarov, E. V.; Ionin, B. I. Khim. Farm. Zh. 1985, 668.

16. Mel'nikov, N. N.; Pesticidy. Khimia tekhnologia i primenenie; Nauka: Moscow, 1987.

17. Gusarova, N. K.; Kuznetsova, E. E.; Shaikhudinova, S. I.; Dmitriev, V. I.; Malysheva, S. F.; Kozlova, G. V.; Trofimov, B. A. Khim. Farm. Zh. 1996, 7, 36.

18. Malysheva, S. F.; Kuznetsova, E. E.; Belogorlova, N. A.; Kozlova, G. V.; Rakhmatulina, T. N.; Al'pert, M. L.; Gusarova, N. K.; Trofimov, B. A. Khim. Farm. Zh. 1998, 11, 24.

19. Wicht, D. K.; Glueck, D. S. In Catalytic Heterofunctionalization. From Hydroamination to Hydrozirconation; Togni, A.; Grutzmacher, H. Eds; Wiley-VCH: Weinheim, 2001; pp 14370.

20. Douglass, M. R.; Stern, C. L.; Marks, T. J. J. Am. Chem. Soc. 2001, 123, 10221.

21. Beletskaya, I. P.; Kazankova, M. A. Zh. Org. Khim. 2002, 38, 1447 [Russ. J. Org. Chem. 2002, 38, 1391 (Engl Transl)].

22. Alonso, F.; Beletskaya, I. P.; Yus, M. Chem. Rev. 2004, 104, 3079.

23. Tanaka, M. Top. Curr. Chem. 2004, 232, 25.

24. Trofimov, B. A. Curr. Org. Chem. 2002, 6, 1121.

25. Trofimov, B. A. In: Modern Problems of Organic Chemistry; VVM: St.-Peterburg, 2004; pp 121-163.

26. Trofimov, B. A.; Gusarova, N. K.; Malysheva, S. F.; Vyalykh, E. P.; Rakhmatulina, T. N.; Voronkov, M. G. Izv. Akad. Nauk, Ser. Khim. 1988, 1449 [Bull. Acad. Sci., Div. Chem. Sci. 1988, 37, 1284 (Engl Transl)].

27. Trofimov, B. A.; Gusarova, N. K.; Malysheva, S. F.; Dmitriev, V. I.; Shaikhudinova, S. I.; Rakhmatulina, T. N. Zh. Org. Khim. 1989, 25, 1563.

28. Gusarova, N. K.; Trofimov, B. A.; Malysheva, S. F.; Rakhmatulina, T. N.; Vyalykh, E. P.; Voronkov, M. G. Izv. Akad. Nauk, Ser. Khim. 1989, 488.

29. Malysheva, S. F.; Gusarova, N. K.; Rakhmatulina, T. N.; Kazantseva, T. I.; Dmitriev, V. I.; Trofimov, B. A. Izv. Akad. Nauk, Ser. Khim. 1989, 1712.

30. Gusarova, N. K.; Trofimov, B. A.; Malysheva, S. F.; Rakhmatulina, T. N.; Voronkov, M. G. Dokl. Akad. Nauk 1989, 305, 355.

31. Trofimov, B. A. Zh. Org. Khim. 1995, 31, 1368. 
32. Sukhov, B. G.; Malysheva, S. F.; Vakul'skaya, T. I.; Tirsky, V. V.; Martynovich, E. F.; Smetannikov, Yu. V.; Tarasova, N. P. ARKIVOC 2003, (xiii), 196.

33. Malysheva, S. F.; Arbuzova, S. N. In: Sovremenniy organicheskiy sintez (Modern Organic Synthesis); Khimiya: Moscow, 2003; pp 160-187.

34. Trofimov, B. A.; Rakhmatulina, T. N.; Gusarova, N. K.; Malysheva, S. F. Usp. Khim. 1991, 60, 2619.

35. Gusarova, N. K.; Brandsma, L.; Arbuzova, S. N.; Malysheva, S. F.; Trofimov, B. A. Zh. Org. Khim. 1996, 32, 269.

36. Trofimov, B. A.; Gusarova, N. K.; Brandsma, L. Main Group Chem. News 1996, 4, 18.

37. Gusarova, N. K.; Malysheva, S. F.; Arbuzova, S. N.; Trofimov, B. A. Izv. Akad. Nauk, Ser. Khim. 1998, 1695 [Russ. Chem. Bull. 1998, 47, 1645 (Engl Transl)].

38. Sukhov, B. G.; Gusarova, N. K.; Malysheva, S. F.; Trofimov, B. A. Izv. Akad. Nauk, Ser. Khim. 2003, 6, 1172 [Russ. Chem. Bull. 2003, 52, 1239 (Engl Transl)].

39. Hoff, M. C.; Hill, P. J. Org. Chem. 1959, 24, 356.

40. Dombek, B. D. J. Org. Chem. 1978, 43, 3408.

41. Malysheva, S. F.; Gusarova, N. K.; Belogorlova, N. A.; Nikitin, M. V.; Gendin, D. V.; Trofimov, B. A. Zh. Obshch. Khim. 1997, 67, 63 [Russ. J. Gen. Chem. 1997, 67, 58 (Engl Transl)].

42. U.S. Patent 2,822, 376: Chem. Abstr. 1958, 52, $10147 \mathrm{~d}$.

43. Rauhut, M. M.; Hechenbleikner, I.; Currier, H. A.; Schaefer, F. C.; Wystrach, V. P. J. Am. Chem. Soc. 1959, 81, 1103.

44. King, R. B.; Kapoor, P. N. J. Am. Chem. Soc. 1969, 91, 5191.

45. King, R. B.; Kapoor, R. N.; Saran, M. C.; Kapoor, P. N. Inorg. Chem. 1971, 10, 1851.

46. King, R. B.; Kapoor, P. N. Angew. Chem. 1971, 83, 766.

47. King, R. B.; Kapoor, P. N. J. Am. Chem. Soc. 1971, 93, 4158.

48. King, R. B.; Cloyd, J. C. Z. Naturforsch B 1972, 27, 1432.

49. King, R. B.; Cloyd, J. C.; Kapoor, P. N. J. Chem. Soc., Perkin. Trans. 1 1973, 19, 2226.

50. King, R. B.; Cloyd, J. C. J. Am. Chem. Soc. 1975, 97, 53.

51. King, R. B.; Cloyd, J. C.; Reimann, R. H. J. Org. Chem. 1976, 41, 972.

52. King, R. B.; Masler, W. F. J. Am. Chem. Soc. 1977, 99, 4001.

53. Trofimov, B. A.; Brandsma, L.; Arbuzova, S. N.; Malysheva, S. F.; Gusarova, N. K. Tetrahedron Lett. 1994, 35, 7647.

54. Trofimov, B. A.; Arbuzova, S. N.; Malysheva, S. F.; Brandsma, L.; Gusarova, N. K. Zh. Obshch. Khim. 1994, 64, 1572.

55. Gusarova, N. K.; Arbuzova, S. N.; Malysheva, S. F.; Khil'ko, M. Ya.; Tatarinova, A. A.; Gorokhov, V. G.; Trofimov, B. A. Izv. Akad. Nauk, Ser. Khim. 1995, 1597 [Russ. Chem. Bull. 1995, 44, 1535 (Engl Transl)].

56. Arbuzova, S. N.; Gusarova, N. K.; Malysheva, S. F.; Brandsma, L.; Albanov, A. I.; Trofimov, B. A. Zh. Obshch. Khim. 1996, 66, 56. 
57. Gusarova, N. K.; Brandsma, L.; Malysheva, S. F.; Arbuzova, S. N.; Trofimov, B. A. Phosph., Sulf. and Silic. and related elem. 1996, 111, 174.

58. Gusarova, N. K.; Trofimov, B. A.; Malysheva, S. F.; Shaikhudinova, S. I.; Belogorlova, N. A.; Arbuzova, S. N.; Nepomnyashchikh, K. V.; Dmitriev, V. I. Zh. Obshch. Khim. 1997, 67, 70 [Russ. J. Gen. Chem. 1997, 67, 65 (Engl Transl)].

59. Trofimov, B. A.; Brandsma, L.; Arbuzova, S. N.; Malysheva, S. F.; Belogorlova, N. A.; Gusarova, N. K. Zh. Obshch. Khim. 1997, 67, 695 [Russ. J. Gen. Chem. 1997, 67, 650 (Engl Transl)].

60. Trofimov, B. A.; Shaikhudinova, S. I.; Dmitriev, V. I.; Nepomnyashchikh, K. V.; Kazantseva, T. I.; Gusarova, N. K. Zh. Obshch. Khim. 2000, 70, 43 [Russ. J. Gen. Chem. 2000, 70, 40 (Engl Transl)].

61. Gusarova, N. K.; Shaikhudinova, S. I.; Kazantseva, T. I.; Malysheva, S. F.; Sukhov, B. G.; Belogorlova, N. A.; Dmitriev, V. I.; Trofimov, B. A. Zh. Obshch. Khim. 2002, 72, 399 [Russ. J. Gen. Chem. 2002, 72, 371 (Engl Transl)].

62. Arbuzov, B. A.; Vinokurova, G. M.; Perfilyeva, I. A. Dokl. Akad. Nauk 1959, 127, 1217.

63. Gundermann, K. D.; Garming, A. Chem. Ber. 1969, 102, 3023.

64. Issleib, K.; Malotki, P. J. Prakt. Chem. 1973, 315, 464.

65. Issleib, K.; Zimmermann, K. Z. Anorg. Allg. Chem. 1977, 436, 20.

66. Kabachnik, M. I.; Medved', T. Ya.; Polikarpov, Yu. M.; Yudina, K. S. Izv. Akad. Nauk, Ser. Khim. 1962, 1584.

67. Pietrusiewicz, M.; Zablocka, M. Tetrahedron Lett. 1988, 29, 1987.

68. Bondarenko, N. A.; Bozhko, O. K.; Tsvetkov, E. N. Izv. Akad. Nauk, Ser. Khim. 1995, 139.

69. Baba, G.; Pilard, J.-F.; Tantaoui, K.; Gaumont, A.-C.; Denis, J.-M. Tetrahedron Lett. 1995, $36,4421$.

70. Gaumont, A.-C.; Simon, A.; Denis, J.-M. Tetrahedron Lett. 1998, 39, 985.

71. Ivanova, N. I.; Gusarova, N. K.; Nikitina, E. A.; Albanov, A. I.; Sinegovskaya, L. M.; Nikitin, M. V.; Konovalova, N. A.; Trofimov, B. A. Phosph., Sulf. and Silic. and related elem. 2004, 179, 7.

72. Trofimov, B. A.; Gusarova, N. K.; Ivanova, N. I.; Konovalova, N. A.; Bogdanova, M. V.; Albanov, A. I.; Avseenko, N. D.; Sukhov, B. G. Zh. Obshch. Khim. 2004, 74, 1748 [Russ. J. Gen. Chem. 2004, 74, 1625 (Engl Transl)].

73. King, R.; Cloyd, J. C.; Hendrick, P. K. J. Am. Chem. Soc. 1973, 95, 5083.

74. Knühl, G.; Sennhenn, P.; Helmchen, G. J. Chem. Soc., Chem. Commun. 1995, 1845.

75. Lavenot, L.; Bortoletto, M. H.; Roucoux, A.; Larpent, C.; Patin, H. J. Organomet. Chem. 1996, 509, 9.

76. Casey, C. P.; Paulsen, E. L.; Beuttenmueller, E. W.; Proft, B. R.; Matter, B. A.; Powell, D. R. J. Am. Chem. Soc. 1999, 121, 63.

77. Brauer, D. J.; Kottsieper, K. W.; Nickel, T.; Stelzer, O.; Sheldrick, W. S. Eur. J. Inorg. Chem. 2001, 1251.

78. Miller, R. C.; Bradley, J. C.; Hamilton, L. A. J. Am. Chem. Soc. 1956, 78, 5299. 
79. Rauhut, M. M.; Currier, H. A. J. Org. Chem. 1961, 26, 4628.

80. Pudovik, A. N.; Sudakova, T. M. Zh. Obshch. Khim. 1971, 41, 1962.

81. Kabachnik, M. I.; Medved', T. Ya.; Goryunova, I. B.; Tikhonova, L. I.; Matrosov, E. I. Izv. Akad. Nauk, Ser. Khim. 1974, 2290.

82. Kharitonov, A. V.; Antoshin, A. E.; Pushin, A. N.; Tsvetkov, E. N. Zh. Obshch. Khim. 1990, $58,1021$.

83. Antoshin, A. E.; Evreinov, V. I.; Kharitonov, A. V.; Pushin, A. N.; Yarkevich, A. N.; Safronova, E. V.; Tsvetkov, E. N. Izv. Akad. Nauk, Ser. Khim. 1991, 1860.

84. Haynes, R. K.; Lam, W. W.-L.; Yeung, L.-L. Tetrahedron Lett. 1996, 37, 4729.

85. Kolesnik, V. D.; Tkachev, A. V. Izv. Akad. Nauk, Ser. Khim. 2002, 4, 620.

86. Bunlaksananusorn, T.; Knochel, P. Tetrahedron Lett. 2002, 43, 5817.

87. Bunlaksananusorn, T.; Knochel, P. J. Org. Chem. 2004, 69, 4595.

88. Gusarova, N. K.; Malysheva, S. F.; Chernysheva, N. A.; Belogorlova, N. A.; Arbuzova, S. N.; Khil'ko, M. Ya.; Trofimov, B. A. Zh. Org. Khim. 1998, 34, 1107.

89. Malysheva, S. F.; Gusarova, N. K.; Belogorlova, N. A.; Arbuzova, S. N.; Sinegovskaya, L. M.; Zefirov, N. S.; Trofimov, B. A. Zh. Obshch. Khim. 1998, 68, 1638 [Russ. J. Gen. Chem. 1998, 68, 1565 (Engl Transl)].

90. Malysheva, S. F.; Gusarova, N. K.; Belogorlova, N. A.; Trofimov, B. A. Sulfur Lett. 1998, 21, 263.

91. Gusarova, N. K.; Bogdanova, M. V.; Ivanova, N. I.; Chernysheva, N. A.; Sukhov, B. G.; Sinegovskaya, L. M.; Kazheva, O, N.; Alexandrov, G. G.; Dyachenko, O. A.; Trofimov, B. A. Synthesis. 2005, 3103.

92. Kapoor, P. N.; Pathak, D. D.; Gaur, G.; Kutty, M. J. Organomet. Chem. 1984, $276,167$.

93. Khachatryan, R. A.; Sayadyan, S. V.; Grigoryan, N. Y.; Indzhikyan, M. G. Zh. Obshch. Khim. 1988, 58, 2472.

94. Gusarova, N. K.; Malysheva, S. F.; Belogorlova, N. A.; Arbuzova, S. N.; Gendin, D. V.; Trofimov, B. A. Zh. Org. Khim. 1997, 33, 1231.

95. Kottsieper, K. W.; Stelzer, O.; Wassersceid, P. J. Molecular. Catalysis A: Chemical 2001, $175,285$.

96. Malysheva, S. F.; Ivanova, N. I.; Belogorlova, N. A.; Khil'ko, M. Ya.; Larina, L. I.; Gusarova, N. K.; Trofimov, B. A. Khim. Geterotsikl. Soedin. 1998, 1195.

97. Ivanova, N. I.; Gusarova, N. K.; Malysheva, S. F.; Belogorlova, N. A.; Kozyreva, O. B.; Skotheim, T.; Trofimov, B. A. Zh. Org. Khim. 1998, 34, 952.

98. Gusarova, N. K.; Ivanova, N. I.; Bogdanova, M. V.; Sinegovskaya, L. M.; Sukhov B. G.; Kopylova, L. I.; Trofimov, B. A. Khim. Geterotsikl. Soedin. 2004, 10, 1584.

99. Robertson, A.; Bradaric, C.; Frampton, C. S.; McNulty, J.; Capretta, A. Tetrahedron Lett. 2001, 42, 2609.

100.Gusarova, N. K.; Ivanova, N. I.; Bogdanova, M. V.; Sinegovskaya, L. M.; Gusarov, A. V.; Trofimov, B. A. Phosph., Sulf. and Silic. and related elem. 2005, 180, 1749. 
101.Rauhut, M. M.; Currier, H. A.; Semsel, A. M.; Wystrach, V. P. J. Org. Chem. 1961, 26, 5138.

102.Arbuzov, B. A.; Vinokurova, G. M.; Aleksandrova, I. A. Izv. Akad. Nauk, Ser. Khim. 1962, 290.

103. Tavs, P. Angew. Chem. 1969, 81, 742.

104.Dilworth, J. R.; Griffiths, D. V.; Hughes, J. M.; Morton, S. Phosph., Sulf. and Silic. and related elem. 1992, 71, 249.

105. Trofimov, B. A.; Gusarova, N. K.; Malysheva, S. F.; Ivanova, N. I.; Sukhov, B. G.; Belogorlova, N. A.; Kuimov, V. A. Synthesis 2002, 2207.

106.Issleib, K.; Weichmann, H. Z. Chem. 1971, 11, 188.

107.Du Bois, D. L.; Myers, W. H. J. Chem. Soc, Dalton Trans. 1975, 1011.

108. Cooper, P.; Fields, R.; Haszeldine, R. N. J. Chem. Soc, Perkin Trans. 1 1975, 702.

109.Heesche-Wagner, K.; Mitchell, T. N. J. Organomet. Chem. 1994, 468, 99.

110.Leca, D.; Fensterbank, L.; Lacôte, E.; Malacria, M. Chem. Soc. Rev. 2005, 34, 858.

111. Arbuzov, B. A.; Vinokurova, G. M. Izv. Akad. Nauk, Ser. Khim. 1963, 502.

112. Mitchell, T. N.; Heesche-Wagner, K. J. Organomet. Chem. 1992, 436, 43.

113.Arpac, E.; Dahlenburg, L. Angew. Chem. 1982, 94, 929.

114.Oehme, H.; Thamm, R. J. Prakt. Chem. 1973, 315, 526.

115.Grobe, J.; Moller, U. J. Organomet. Chem. 1971, 31, 157.

116. Couret, C.; Escudie, J.; Satge, J.; Andrimizaka, J. D.; Saint-Roch, B. J. Organomet. Chem. 1979, $182,9$.

117. Arbuzova, S. N.; Brandsma, L.; Gusarova, N. K.; Trofimov, B. A. Rec. Trav. Chim. PaysBas 1994, 113, 575.

118. Trofimov, B. A.; Sukhov, B. G.; Malysheva, S. F.; Belogorlova, N. A.; Tantsirev, A. P.; Parshina, L. N.; Oparina, L. A.; Tunik, S. P.; Gusarova, N. K. Tetrahedron Lett. 2004, 45, 9143.

119. Trofimov, B. A.; Malysheva, S. F.; Sukhov, B. G.; Belogorlova, N. A.; Schmidt, E. Yu.; Sobenina, L. N.; Kuimov, V. A.; Gusarova, N. K. Tetrahedron Lett. 2003, 44, 2629.

120. Trofimov, B. A.; Gusarova, N. K.; Sukhov, B. G.; Malysheva, S. F.; Tarasova, O. A.; Belogorlova, N. A.; Maximova, M. A.; Tunik, S. P. Synthesis 2005, 965.

121. Trzeciak, A. M.; Glowiak, T.; Ziolkowski, J. J. J. Organomet. Chem. 1998, 552, 159.

122.Guo, R.; Li, X.; Wu, J.; Kwok, W. H.; Chen, J.; Choi, M. C. K.; Chan, A. S. C. Tetrahedron Lett. 2002, 43, 6803.

123. Mukherjee, A.; Sarkar, A. ARKIVOC 2003, (ix), 87.

124.Fr. Patent 2082398: Ref. Zh. Khim. 1973, 2N109P.

125.B.R.D. Patent 1912708: Ref. Zh. Khim. 1978, 17N91P.

126.B.R.D. Patent 2040280: Ref. Zh. Khim. 1979, 22N108P.

127.B.R.D. Patent 2064574: Ref. Zh. Khim. 1982, 8N95P.

128. Chauzov, V. A.; Kostina, L. P. Zh. Obshch. Khim. 1991, 61, 1265.

129.Jessop, C. M.; Parsons, A. F.; Routledge, A.; Irvine, D. Tetrahedron Lett. 2003, 44, 479. 
130.Rey, P.; Taillades, J.; Rossi, J. C.; Gros, G. Tetrahedron Lett. 2003, 44, 6169.

131. Maier, L. Helv. Chim. Acta. 1966, 49, 1249.

132. Niebergall, H. Makromol. Chem. 1962, 52, 218.

133.Dingwall, J.G.; Tuck, B. J. Chem. Soc., Perkin Trans. 1 1986, 2081.

134.Gusarova, N. K.; Ivanova, N. I.; Bogdanova, M. V.; Malysheva, S. F.; Belogorlova, N. A.;

Sukhov, B. G.; Trofimov, B. A. Mendeleev Commun. 2004, 216.

135.Parsons, A. F.; Sharpe, D. J.; Taylor, P. Synlett. 2005, 1, 1.

136. Well, M.; Schmutzler, R. Phosph., Sulf. and Silic. and related elem. 1992, 72, 171.

137. Braunstein, P.; Naud, F. Angew. Chem. 2001, 40, 681.

138.Hayashi, M.; Takezaki, H.; Hashimoto, Y.; Takaoki, K.; Saigo, K. Tetrahedron Lett. 1998, $39,7529$.

139.Cullen, W. R.; Dawson, D. S.; Styan, G. E. Can. J. Chem. 1965, 43, 3392.

140.Hoffmann, H.; Diehr, H. J. Chem. Ber. 1965, 98, 363.

141. Aguiar, A. M.; Archibald, T. G. Tetrahedron Lett. 1966, 45, 5541.

142. Shaw, M. A.; Tebby, J. C. J. Chem. Soc. (C) 1970, 5.

143.Märkl, G.; Dannhardt, G. Tetrahedron Lett. 1973, 17, 1455.

144. Schoufs, M.; Meijer, J.; Vermeer, P. Rec. Trav. Chim. Pays-Bas 1974, 93, 241.

145.Berger, H. O.; Nöth, H. J. Organomet. Chem. 1983, 250, 33.

146.Kostyanovsky, R. G.; El'natanov, Yu. I. Izv. Akad. Nauk, Ser. Khim. 1983, 2581.

147.El'natanov, Yu. I.; Kostyanovsky, R. G. Izv. Akad. Nauk, Ser. Khim. 1988, 382.

148. Schmidbaur, H.; Frazão, C. M.; Reber, G.; Müller, G. Chem. Ber. 1989, 122, 259.

149.Bookham, J. L.; McFarlane, W.; Thornton-Pett, M.; Jones, S. J. Chem. Soc., Dalton Trans.

1990, 12, 3621 .

150. Mitchell, T. N.; Heesche, K. J. Organomet. Chem. 1991, 409, 163.

151.Karlsted, N. B.; Borisenko, A. A.; Foss, V. L. Zh. Obshch. Khim. 1992, 62, 1516.

152. Khachatryan, R. A.; Grigoryan, N. Y.; Indzhikyan, M. G. Zh. Obshch. Khim. 1994, 64, 1260 .

153. Gusarova, N. K.; Malysheva, S. F.; Arbuzova, S. N.; Brandsma, L.; Trofimov, B. A. Zh. Obshch. Khim. 1994, 64, 2062.

154.Brumwell, J. E.; Simpkins, N. S.; Terrett, N. K. Tetrahedron 1994, 50, 13533.

155. Trofimov, B. A.; Gusarova, N. K.; Arbuzova, S. N.; Malysheva, S. F.; den Besten, R.; Brandsma, L. Synthesis 1995, 387.

156.Bookham, J. L.; Smithies, D. M.; Wright, A.; Thornton-Pett, M.; McFarlane, W. J. Chem. Soc., Dalton Trans. 1998, 5, 811.

157.Trofimov, B. A.; Arbuzova, S. N.; Mal'kina, A. G.; Gusarova, N. K.; Malysheva, S. F.; Nikitin, M. V.; Vakul'skaya, T. I. Mendeleev Commun. 1999, 163.

158.D’yachkova, S. G.; Gusarova, N. K.; Nikitin, M. V.; Aksamentova, T. N.; Chipanina, N. N.; Nikitina, E. A.; Trofimov, B. A. Zh. Obshch. Khim. 2001, 71, 1812 [Russ. J. Gen. Chem. 2001, 71, 1717 (Engl Transl)]. 
159. Malysheva, S. F.; Sukhov, B. G.; Larina, L. I.; Belogorlova, N. A.; Gusarova, N. K.; Trofimov, B. A. Zh. Obshch. Khim. 2001, 71, 2012 [Russ. J. Gen. Chem. 2001, 71, 1907 (Engl Transl)].

160. Gusarova, N. K.; Shaikhudinova, S. I.; Arbuzova, S. N.; Vakul'skaya, T. I.; Sukhov, B. G.; Sinegovskaya, L. M.; Nikitin, M. V.; Mal'kina, A. G.; Chernysheva, N. A.; Trofimov, B. A. Tetrahedron 2003, 59, 4789.

161. Trofimov, B. A.; Sukhov, B. G.; Malysheva, S. F.; Belogorlova, N. A.; Arbuzova, S. N.; Tunik, S. P.; Gusarova, N. K. Zh. Org. Khim. 2004, 40, 138.

162.Arbuzova, S. N.; Shaikhudinova, S. I.; Gusarova, N. K.; Nikitin, M. V.; Mal'kina, A. G.; Sukhov, B. G.; Bogdanova, M. V.; Trofimov, B. A. Zh. Obshch. Khim. 2005, 75, 552.

163. Arbuzova, S. N.; Gusarova, N. K.; Bogdanova, M. V.; Ivanova, N. I.; Ushakov, I. A.; Mal'kina, A. G.; Trofimov, B. A. Mendeleev Commun. 2005, 5, 183.

164.Herd, O.; Hebter, A.; Hingst, M.; Machnitzki, R.; Tepper, M.; Stelzer, O. Catal. Today 1998, $42,413$.

165.Duncan, M.; Gallagher, M. J. Org. Magn. Res. 1981, 15, 37.

166. Gusarova, N. K.; Reutskaya, A. M.; Ivanova, N. I.; Medvedeva, A. S.; Demina, M. M.; Novopashin, P. S.; Afonin, A. V.; Albanov, A. I.; Trofimov B. A. J. Organomet. Chem. 2002, 659, 172.

167.Dickstein, J. I.; Miller, S. I. In: The Chemistry of the Carbon-Carbon Triple Bond, Part 2; Patai, S. Ed.; John Wiley: New York, 1978; pp 813-955.

168.D’yachkova, S. G.; Nikitin, M. V.; Beskrylaya, E. A.; Arbuzova, S. N.; Kashik, T. V.; Gusarova, N. K.; Trofimov, B. A. Zh. Obshch. Khim. 1999, 69, 799 [Russ. J. Gen. Chem. 1999, 69, 767 (Engl Transl)].

169.D’yachkova, S. G.; Gusarova, N. K.; Nikitin, M. V.; Malysheva, S. F.; Dolenko, G. N.; Sinegovskaya, L. M.; Mamaseva, T. V.; Trofimov, B. A. Zh. Obshch. Khim. 1999, 69, 1296 [Russ. J. Gen. Chem. 1999, 69, 1247 (Engl Transl)]. 